\title{
Synedrella nodiflora (Linn.) Gaertn. inhibits inflammatory responses through the regulation of Syk in RAW 264.7 macrophages
}

\author{
HIEN THI THU LE ${ }^{1 *}$, JIYOUNG PARK $^{1 *}$, JAIN HA $^{1}$, \\ SUSI KUSUMANINGRUM ${ }^{2}$, JIN HYUB PAIK ${ }^{3}$ and SAYEON CHO ${ }^{1}$
}

\begin{abstract}
${ }^{1}$ Laboratory of Molecular and Pharmacological Cell Biology, College of Pharmacy, Chung-Ang University, Seoul 06974, Republic of Korea; ${ }^{2}$ Center for Pharmaceutical and Medical Technology, Deputy for Agroindustrial Technology and Biotechnology, The Agency for the Assessment and Application of Technology (BPPT), Tangerang, Banten 15310, Indonesia; ${ }^{3}$ International Biological Material Research Center, Korean Research Institute of Bioscience and Biotechnology, Daejeon 34141, Republic of Korea
\end{abstract}

Received September 11, 2019; Accepted March 03, 2020

DOI: $10.3892 /$ etm.2020.8750

\begin{abstract}
Synedrella nodiflora (Linn.) Gaertn. (S. nodiflora) has long been used for the treatment of inflammatory diseases, including liver disease, asthma, rheumatism and earache, in tropical countries throughout America, Asia and Africa. However, the biological effects of $S$. nodiflora have not been extensively studied at the molecular level. Notably, it remains unclear how S. nodiflora exerts anti-inflammatory activity. In the present study, the anti-inflammatory mechanism of a methanol extract of S.nodiflora (MSN) inRAW264.7 macrophagesactivatedbylipopolysaccharide (LPS) was investigated. Non-cytotoxic concentrations of MSN $(\leq 400 \mu \mathrm{g} / \mathrm{ml})$ decreased the expression of inducible nitric oxide synthase (iNOS) and cyclooxygenase-2 (COX-2), which resulted in a decrease in nitric oxide and prostaglandin $\mathrm{E}_{2}$ $\left(\mathrm{PGE}_{2}\right)$ production. The mRNA expression of pro-inflammatory cytokines such as interleukin (IL)-6, IL-1 $\beta$, and tumor necrosis factor (TNF)- $\alpha$ was reduced upon MSN treatment. In addition, the activation of spleen tyrosine kinase (Syk) and Akt was suppressed by MSN. Taken together, these findings recommend the traditional medicinal application of $S$. nodiflora in the treatment of several inflammation-associated diseases and indicate the possibility of MSN as a novel therapeutic reagent of inflammation-related diseases.
\end{abstract}

Correspondence to: Dr Sayeon Cho, Laboratory of Molecular and Pharmacological Cell Biology, College of Pharmacy, Chung-Ang University, 84 Heukseok-Ro, Dongjak-Gu, Seoul 06974, Republic of Korea

E-mail: sycho@cau.ac.kr

${ }^{*}$ Contributed equally

Key words: synedrella nodiflora, macrophages, lipopolysaccharide, inflammatory mediators, nuclear factor- $\varkappa \mathrm{B}$, spleen associated tyrosine kinase

\section{Introduction}

A living organism continually faces intrusion by various pathogens such as bacteria, viruses and fungi. Inflammatory reactions occur to protect the organism from extracellular threats (1). The intensity and duration of inflammatory responses are dependent on the balance between pro-inflammatory and anti-inflammatory mediators (2). Therefore, an imbalance in these mediators causes severe cellular damage that can lead to chronic inflammatory disorders, including rheumatoid arthritis, autoimmune diseases, cancers and atherosclerosis (3). Macrophages function as a first alarm of the defense system against common pathogens and are activated in response to cytokines and pathogen-associated molecular patterns such as lipopolysaccharide (LPS), flagellin, and lipoteichoic acid (4-6). Toll-like receptor 4 (TLR4) at the surface of immune cells recognizes LPS, which is a cell-wall component of gram-negative bacteria (7). In the presence of LPS, activated macrophages induce a wide range of pro-inflammatory mediators, including tumor necrosis factor (TNF)- $\alpha$, interleukin (IL)-1 $\beta$, IL-6, nitric oxide (NO), and prostaglandin $\mathrm{E}_{2}\left(\mathrm{PGE}_{2}\right)$, to stimulate other immune cells $(8,9)$. Pro-inflammatory cytokines exert biological activities related to acute or chronic inflammatory diseases (10). TNF- $\alpha$ is a potent stimulator of inducible nitric oxide synthase (iNOS) expression in vascular smooth muscle cells (11). When activated, iNOS produces a high concentration of $\mathrm{NO}$, a regulatory molecule of various physiological functions such as vasodilatation (12). Another major event during inflammation is the arachidonic acid cascade produced from membrane phospholipids (13). Arachidonic acid is degraded by cyclooxygenase (COX) to prostaglandins (PGs), which mediates inflammatory responses (13). COX-2 is induced by cytokines and is responsible for releasing a high concentration of $\mathrm{PGE}_{2}(14,15)$. Both $\mathrm{NO}$ and $\mathrm{PGE}_{2}$ are involved in pain-induction and -perception (16). These inflammatory mediators function to protect the host cells from infection. However, the unnatural expression or activation of inflammatory mediators is associated with inflammatory 
disease $(17,18)$. RAW 264.7 is a monocyte/macrophage-like Abelson leukemia virus transformed cell line derived from $\mathrm{BALB} / \mathrm{c}$ mice. This cell line is a commonly used model of mouse macrophages for the study of cellular responses to anti-inflammatory extracts. Upon stimulation with LPS, RAW 264.7 cells increase nitric oxide (NO) production and enhance phagocytosis. Furthermore, these cells are able to kill target cells by antibody-dependent cytotoxicity (19). The RAW 264.7 cell line is designed to grow and differentiate more stably than other macrophage cells. These cells are suitable for monitoring anti-inflammatory mechanisms mediated by various cytokines or LPS (20).

In folk medicinal remedies, Synedrella nodiflora (Linn.) Gaertn. (S.nodiflora), which belongs to the Asteraceae family, has been used for the prevention and treatment of diverse diseases in Asia. It is a traditional plant of tropical America and is also found in Ghana, India, China, Malaysia, Japan, and other Indopacific countries (21). In Ghana, traditional medical practitioners have used aqueous extracts of $S$. nodiflora for epilepsy and pain management after boiling the whole plant (22). S. nodiflora has been treated as an external medicine to cure earache, headache, and inflammation in Malaysia (23). The leaves of $S$. nodiflora have also been used to treat stomachache and hiccup and in threatened abortion cases (24). Furthermore, a methanol extract of $S$. nodiflora leaves (MSN) proved to have insecticidal, sedative, anti-oxidative, anti-convulsant, and anti-inflammatory effects $(25,26)$. The components of MSN are already well reported by many researchers $(21,27,28)$. The phytochemical profile indicates that extracts of $S$. nodiflora contain alkaloids, flavonoids, triterpenes, saponins, simple phenolics, glycosides, and polyose $(29,30)$. Glycosides suppress the expression of inflammatory mediators via TNF- $\alpha$ inhibition (31). Triterpenes inhibit nuclear factor (NF)- $\varkappa B$-regulated gene expression and transforming growth factor- $\beta$-activated kinase 1 (TAK1)-mediated NF- $\varkappa \mathrm{B}$ activation (32). In general, flavonoids regulate the inflammatory responses associated with activating protein- 1 or $\mathrm{NF}-\varkappa \mathrm{B}$, thereby suppressing chronic inflammatory diseases $(33,34)$. Several researchers have reported that total alkaloids show anti-inflammatory effects and regulate proto-oncogene tyrosine-protein kinase (Src)/spleen tyrosine kinase (Syk) of NF- $x \mathrm{~B}$ signaling (35). Saponins have been reported to suppress the inflammatory response by inhibiting the PI3K/Akt signaling pathway in macrophages (36).

Although S. nodiflora has been evaluated for its pharmacological activities, there has been no systematic study of the mechanisms underlying the anti-inflammatory effects of MSN. Therefore, this study focused on the analysis of the potential anti-inflammatory effects of MSN at the protein level in macrophages activated by LPS.

\section{Materials and methods}

MSN preparation. S. nodiflora was collected from the Slamet Mountains, Central Java, Indonesia. Plant samples were collected and identified by staff at the Center for Pharmaceutical and Medical Technology (PTFM), and verified at the Herbarium Bogoriense (LIPI). Voucher specimens recorded as KRIB 0039477 and PMT 1171, were deposited in the herbarium (KRIB) of the Korean Research Institute of Bioscience and Biotechnology (Daejeon, Korea) as well as in the Center for Pharmaceutical and Medical Technology (PTFM) and the Herbarium Bogoriense. The extract was deliquesced in dimethyl sulfoxide (DMSO; Sigma-Aldrich; Merck $\mathrm{KGaA}$ ) and added to the culture media to the final concentration as indicated. It was confirmed that $S$. nodiflora is not a protected or endangered species $(37,38)$.

Cell culture and reagents. RAW 264.7 macrophages were purchased from ATCC.RAW 264.7 cells were cultured under the following condition: $10 \%$ fetal bovine serum (FBS, Invitrogen; Thermo Fisher Scientific, Inc.) and 1\% penicillin/streptomycin (Thermo Fisher Scientific, Inc.) in Dulbecco's modified Eagle's medium (DMEM; Invitrogen; Thermo Fisher Scientific, Inc.) at $37^{\circ} \mathrm{C}$ in $5 \% \mathrm{CO}_{2}$. LPS for activation of RAW 264.7 cells was purchased from Sigma-Aldrich; Merck KGaA.

Cell viability assay. RAW 264.7 cells were seeded in 96-well plates $\left(4.5 \times 10^{4}\right.$ cells/well), pre-treated with $\operatorname{MSN}(100,200$, 300,400 and $600 \mu \mathrm{g} / \mathrm{ml}$ ) for $2 \mathrm{~h}$, and then incubated with LPS $(1 \mu \mathrm{g} / \mathrm{ml})$ at $37^{\circ} \mathrm{C}$ for $24 \mathrm{~h}$. The cell viability was measured using the EZ-Cytox cell viability assay kit (Daeil Tech Co., Ltd.) according to the manufacturer's instructions. Cell viability was calculated following the absorbance for viable cells at $450 \mathrm{~nm}$ and reference absorbance at $650 \mathrm{~nm}\left(\mathrm{~A}_{450}-\mathrm{A}_{650}\right)$ with the Synergy H1 Microplate Reader (BioTek Instruments, Inc.).

Nitrite assay. Cells $\left(4.5 \times 10^{4}\right.$ cells/well; 96-well plate) were incubated with MSN $(100,200,300$ and $400 \mu \mathrm{g} / \mathrm{ml})$ for $2 \mathrm{~h}$ and then with LPS $(1 \mu \mathrm{g} / \mathrm{ml})$ at $37^{\circ} \mathrm{C}$ for $24 \mathrm{~h}$. Nitrite assay was performed as described in a previous study (39).

Reverse transcription-quantitative polymerase chain reaction $(R T-q P C R)$. RAW 264.7 cells $\left(2 \times 10^{5}\right.$ cells/well; 12-well plate) were pre-treated with MSN $(100,200,300$ and $400 \mu \mathrm{g} / \mathrm{ml})$ for $2 \mathrm{~h}$ and activated by LPS $(1 \mu \mathrm{g} / \mathrm{ml})$ for $3 \mathrm{~h}$ at $37^{\circ} \mathrm{C}$. Total RNA preparation, cDNA synthesis, and quantification of mRNA were performed as previously described (39). Quantification of gene expression was analyzed using the $2^{-\Delta \Delta C q}$ method (40). Calculated gene expression was normalized to reference genes, glyceraldehyde 3-phosphate dehydrogenase (GAPDH) and $\beta$-actin. The sequences of the PCR primers are listed in a previous study (41).

Enzyme-linked immunosorbent assay (ELISA). RAW 264.7 macrophages were seeded in 96 -well plates $\left(4.5 \times 10^{4}\right.$ cells/well) and incubated at $37^{\circ} \mathrm{C}$ overnight. The cells were pre-treated with MSN (100, 200, 300 and $400 \mu \mathrm{g} / \mathrm{ml})$ for $2 \mathrm{~h}$ and then incubated with LPS $(1 \mu \mathrm{g} / \mathrm{ml})$ at $37^{\circ} \mathrm{C}$ for $24 \mathrm{~h}$. Culture supernatants were collected by centrifugation at $1,500 \mathrm{x}$ g for $1 \mathrm{~min}$ at room temperature (RT). ELISA kit for the detection of IL-6 (cat. no. 88-7064) and TNF- $\alpha$ (cat. no. 88-7324) were from eBioscience (Thermo Fisher Scientific, Inc.). TNF- $\alpha$ and IL-6 levels in cell supernatants were measured using sandwich ELISA with monoclonal antibodies specific to each mediator according to the manufacturer's instructions. Briefly, a 96-well-ELISA plate was pre-coated with the capture antibody at $4^{\circ} \mathrm{C}$ for overnight. The plate was washed 4 times with 
1X phosphate-buffered saline (PBS)/5\% Tween 20 (PBST) and blocked with $1 \mathrm{X}$ assay diluent at RT for $1 \mathrm{~h}$. Then, $100 \mu \mathrm{l}$ of the sample was added to each well and incubated at RT for 2 h. Subsequently, a biotinylated detection antibody solution was added at RT for $1 \mathrm{~h}$. After this, the plate was treated with HRP-streptavidin solution at RT for $30 \mathrm{~min}$, and then $100 \mu \mathrm{l}$ of 3,3',5,5'-tetramethylbenzidine was added for further incubation at $\mathrm{RT}$ for $10 \mathrm{~min}$ in the dark. The further reaction was blocked by adding $50 \mu \mathrm{l}$ of $1 \mathrm{~N} \mathrm{H}_{3} \mathrm{PO}_{4}$. The absorbance was measured (450 nm) with a Synergy H1 Microplate Reader. The concentrations of the secreted cytokines were calculated based on a standard curve.

Preparation of total cell lysates. RAW 264.7 cells were treated with MSN (100, 200, 300 and $400 \mu \mathrm{g} / \mathrm{ml})$ at $37^{\circ} \mathrm{C}$ for $2 \mathrm{~h}$ and then stimulated with LPS $(1 \mu \mathrm{g} / \mathrm{ml})$ at $37^{\circ} \mathrm{C}$ for $3 \mathrm{~min}$ (for $\mathrm{I} \varkappa \mathrm{B} \alpha$, Src, Syk, Akt, TAK1), $15 \mathrm{~min}$ (for MAPKs), or $24 \mathrm{~h}$ (for iNOS and COX-2), and subsequently washed twice with cold PBS (pH 7.4). Cells were collected and lysed in lysis buffer containing $150 \mathrm{mM} \mathrm{NaCl}, 20 \mathrm{mM}$ trisaminomethane hydrochloride (Tris- $\mathrm{HCl}$ ) (pH 8.0), 0.5\% IGEPAL CA-630 (NP-40), $1 \mathrm{mM}$ ethylenediaminetetraacetic acid, $0.5 \%$ Triton $\mathrm{X}-100$, $1 \%$ glycerol, $10 \mathrm{mM}$ sodium fluoride, $2 \mathrm{mM}$ phenylmethylsulfonyl fluoride, and $1 \mathrm{mM}$ sodium orthovanadate. The lysates were centrifuged at $15,814 \mathrm{xg}$ at $4^{\circ} \mathrm{C}$ for $30 \mathrm{~min}$. Supernatants were transferred to a new tube.

Immunoblot analysis. Briefly, the protein concentration was measured using Bradford protein assay (Bio-Rad) according to the manufacturer's instructions. Aliquots of cell lysates were mixed with 5X sodium dodecyl sulfate (SDS)-polyacrylamide sample buffer including $12 \mathrm{mM}$ Tris- $\mathrm{HCl}$ ( $\mathrm{pH} 6.8), 5 \%$ glycerol, $1 \% \beta$-mercaptoethanol, $0.4 \%$ SDS, and $0.02 \%$ bromophenol blue and boiled at $95^{\circ} \mathrm{C}$ for $5 \mathrm{~min}$. Samples were separated on $10 \%$ SDS-polyacrylamide gels and transferred to nitrocellulose membranes (GE Healthcare). The membranes were blocked with $5 \%$ nonfat-dried skim milk in $1 \mathrm{X}$ TBST solution, followed by incubation at $4{ }^{\circ} \mathrm{C}$ overnight with the following primary antibodies: Mouse polyclonal anti-p38 (cat no. sc-7972), mouse monoclonal anti-c-Jun N-terminal kinase (JNK; cat no. sc-7345), rabbit polyclonal phosphorylated (p)-anti-I $x \mathrm{~B} \alpha$ (Ser32/36; cat no. sc-101713), mouse polyclonal anti-spleen tyrosine kinase (Syk; cat no. sc-1240), mouse monoclonal anti-c-proto-oncogene tyrosine-protein kinase Src (c-Src; cat no. sc-19), rabbit polyclonal anti-p-c-Src (Tyr424; cat no. sc-81521), rabbit polyclonal anti-Akt1/2/3 (cat no. sc-8312), rabbit polyclonal anti-p-Akt1/2/3 (Ser473; cat no. sc-7985), goat polyclonal anti-cyclooxygenase 2 (COX-2; cat no. sc-1745), rabbit polyclonal anti-inducible NO synthase (iNOS; cat no. sc-651) and mouse monoclonal anti- $\alpha$-tubulin (cat no. sc-5286) antibodies were purchased from Santa Cruz Biotechnology, Inc. Rabbit polyclonal transforming growth factor- $\beta$-activated kinase 1 (TAK1; cat no. 4505), rabbit monoclonal anti-p-TAK1 (Thr184/187; cat no. 4508), rabbit polyclonal anti-p-p38 (Thr180/Tyr182; cat no. 9211), rabbit polyclonal anti-extracellular signal-regulated kinase (ERK; cat no. 9102), rabbit monoclonal anti-p-ERK (Thr202/Tyr204; cat no. 9106), rabbit polyclonal anti-p-JNK (Thr183/Tyr185; cat no. 9252) and rabbit polyclonal anti-p-Syk (Tyr525/526; cat no. 2711) antibodies were purchased from Cell Signaling
Technology, Inc. All primary antibodies were diluted to 1:1,000 in 5\% non-fat dried milk. Each membrane was washed 4 times with $1 \mathrm{X}$ TBST and incubated with the following secondary antibodies: Polyclonal anti-rabbit IgG-HRP (1:5,000; cat no. LF-SA8002) and polyclonal anti-mouse IgG Fc-HRP (1:5,000; cat no. LF-SA8001) were from AbFrontier; Young In Frontier Co., Ltd., at RT for 2 h. Each protein level was visualized using an enhanced chemiluminescence (ECL) immunoblotting detection reagent (Pierce; Thermo Fisher Scientific, Inc.). Protein levels were scanned and analyzed with LabWorks v.4.0 software (UVP Inc.).

Statistical analysis. All experiments were performed 3 times. The results are represented as means \pm standard error of the mean (SEM). Differences between experimental conditions were assessed using one-way ANOVA followed by Tukey's test in Prism v.3.0 (GraphPad Software, Inc.). $\mathrm{P}<0.05$ was concidered to indicate a statistically significant difference.

\section{Results}

Effect of MSN on cell viability. Since ethnopharmacological records indicate that $S$. nodiflora has been shown to exhibit potent anti-inflammatory effects (42), MSN was evaluated to identify its molecular mechanisms of action in the present study. To determine the maximal non-cytotoxic concentration of MSN, a cell viability assay was performed. RAW 264.7 cells were treated with MSN in the presence or absence of LPS. The cell viability was not altered until treatment with $400 \mu \mathrm{g} / \mathrm{ml}$ of MSN (Fig. 1A). When cells were treated with $600 \mu \mu \mathrm{g} / \mathrm{ml}$ of MSN, cell viability was significantly reduced. Therefore, concentrations $<400 \mu \mathrm{g} / \mathrm{ml}$ of MSN were used in the subsequent experiments.

Inhibitory effect of MSN on the production of nitric oxide (NO) in LPS-stimulated macrophages. NO is an essential cellular signaling molecule involved in diverse physiological and pathological processes in mammals (43). In the inflammatory response, NO levels are increased due to induced iNOS in cells, and the produced NO plays a dual role in immune and inflammatory responses (44). To investigate the anti-inflammatory effects of MSN, the MSN-regulated NO expression was examined in LPS-stimulated macrophages that showed inflammatory responses. MSN effectively inhibited NO production in a dose-dependent manner (Fig. 1B). Since iNOS is the essential enzyme of NO production, iNOS expression at the mRNA and protein levels following MSN treatment was evaluated. RT-qPCR analysis showed that upregulated iNOS expression by LPS stimulation was suppressed following MSN treatment (Fig. 1C). In addition, immunoblot analysis showed that increased protein expression of iNOS by LPS treatment was dose-dependently reduced by MSN (Fig. 1D). These results suggest that MSN negatively regulates NO production by suppression of iNOS at the transcriptional level.

Inhibitory effect of MSN on the production of pro-inflammatory mediators. Since COX-2 catalyzes the production of $\mathrm{PGE}_{2}$, which causes fever, diarrhea, and excessive uterine contraction (45), the anti-inflammatory effects of MSN were assessed by evaluating mRNA and protein expression of 
A
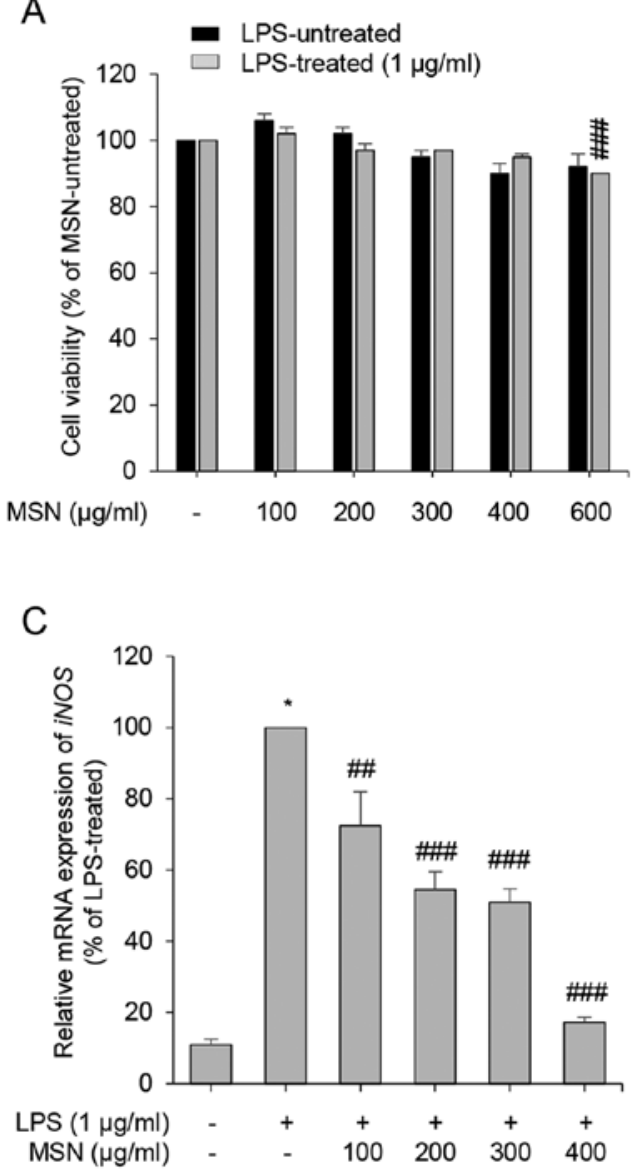

B

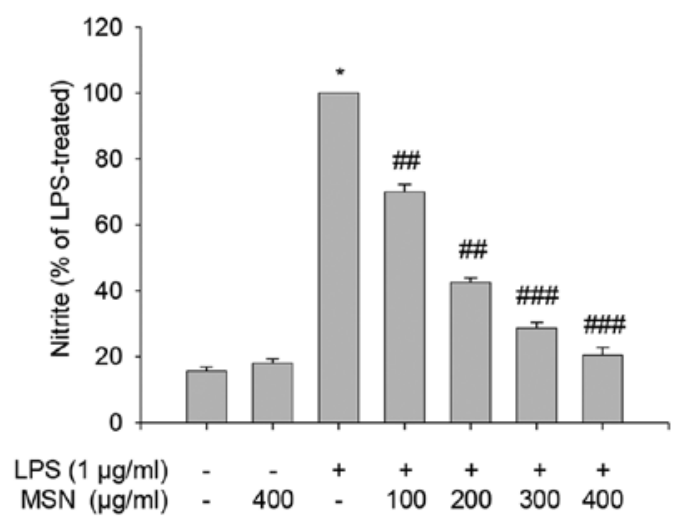

D
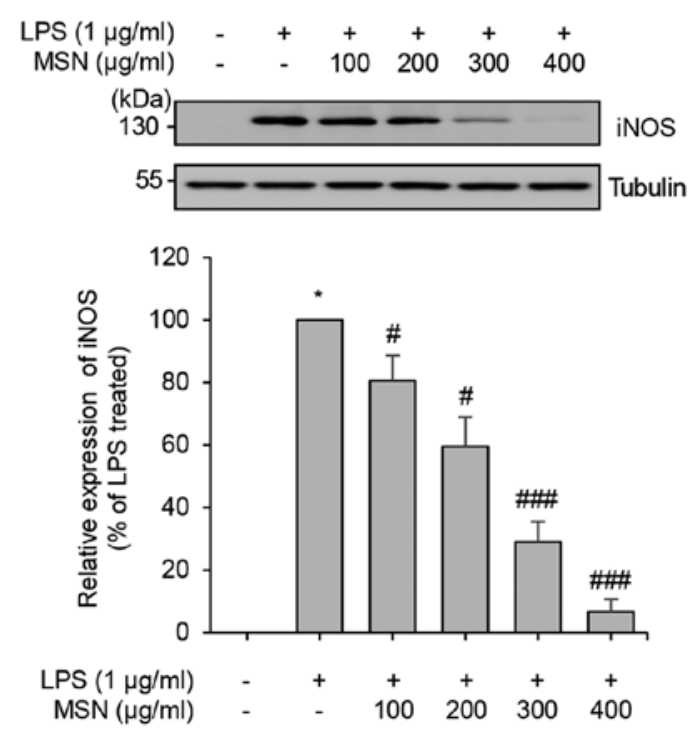

Figure 1. Effect of MSN on cell viability. (A) RAW 264.7 macrophages were treated with MSN $(100,200,300,400$ and $600 \mu \mathrm{g} / \mathrm{ml})$ at $37^{\circ} \mathrm{C}$ for $2 \mathrm{~h}$ and incubated in the absence or presence of LPS $(1 \mu \mathrm{g} / \mathrm{ml})$ at $37^{\circ} \mathrm{C}$ for an additional $24 \mathrm{~h}$. The cell viability was examined using EZ-Cytox assay kit. Cell viability of each group was calculated based on the LPS-treated or LPS-untreated control group. (B) RAW 264.7 macrophages were pre-treated with MSN (100, 200, 300, and $400 \mu \mathrm{g} / \mathrm{ml})$ at $37^{\circ} \mathrm{C}$ for $2 \mathrm{~h}$ and then stimulated with LPS $(1 \mu \mathrm{g} / \mathrm{ml})$. After $24 \mathrm{~h}$ stimulation, the levels of NO secretion in the culture media were measured using Griess reagent. The amounts of NO secretion were calculated according to a standard curve according to a nitrite standard solution. (C) Total cell lysates were collected after $24 \mathrm{~h}$ LPS stimulation, and RT-qPCR analysis was performed. Relative expression levels of iNOS are represented as a bar graph. (D) After $3 \mathrm{~h}$ LPS stimulation, iNOS was analyzed by immunoblotting. The expression of $i N O S$ was detected using ECL reagent and quantified by analysis with LabWorks software. All the protein levels were normalized to corresponding tubulin levels. Data are represented as the mean \pm SEM. "P<0.01 vs. LPS-untreated control group. ${ }^{\#} \mathrm{P}<0.05,{ }^{\# \#} \mathrm{P}<0.01$ and ${ }^{\# \# \#} \mathrm{P}<0.001$ vs. LPS-treated and MSN-untreated control group. MSN, methanol extract of Synedrella nodiflora (Linn.) Gaertn.; LPS, lipopolysaccharide; iNOS, inducible nitric oxide synthase.

COX-2. LPS-induced expression of COX-2 gene and COX-2 protein was suppressed by MSN in a dose-dependent manner (Fig. 2A and B). Therefore, these results suggest that MSN regulates COX-2 in LPS-activated macrophages through the inhibition of the COX-2 gene and COX-2 protein expression.

To further investigate the anti-inflammatory effects of MSN, the production of pro-inflammatory cytokines, which are induced by LPS in macrophages, was measured in the presence or absence of MSN. As shown in Fig. 2C and D, pro-inflammatory cytokines including IL- 6 and TNF- $\alpha$ were significantly increased upon stimulation with LPS and decreased by MSN treatment. The effect of MSN on the gene expression of pro-inflammatory cytokines, including IL-6, IL-1 $\beta$, and TNF- $\alpha$, was also analyzed using RT-qPCR. The mRNA expression of the pro-inflammatory cytokine genes was inhibited by MSN in LPS-activated RAW 264.7 macrophages (Fig. 2E). Taken together, these results suggest that MSN suppresses the LPS-induced production of pro-inflammatory cytokines by inhibition of $I L-6, I L-1 \beta$, and $T N F-\alpha$ transcription.

Differential inhibitory role of MSN on MAPK and NF- $x B$ in $R A W 264.7$ macrophages. NF- $x \mathrm{~B}$ and mitogen-activated protein kinase (MAPK) regulate the genes involved in inflammatory responses of RAW 264.7 cells (46). Phosphorylation at $\operatorname{Ser} 32 / 36$ of $\mathrm{I} x \mathrm{~B} \alpha$ was found to lead to the degradation of $\mathrm{I} x \mathrm{~B} \alpha$ bound to NF- $x \mathrm{~B}$, and freed and activated NF- $x \mathrm{~B}$ translocated to the nucleus, inducing transcription of target inflammatory genes (47). We, therefore, measured the phosphorylation levels at Ser32/36 of $\mathrm{I} \gamma \mathrm{B} \alpha$ and the protein level of $\mathrm{I} \alpha \mathrm{B} \alpha$ to examine whether MSN caused a change in $\mathrm{I} \alpha \mathrm{B} \alpha$ 
A

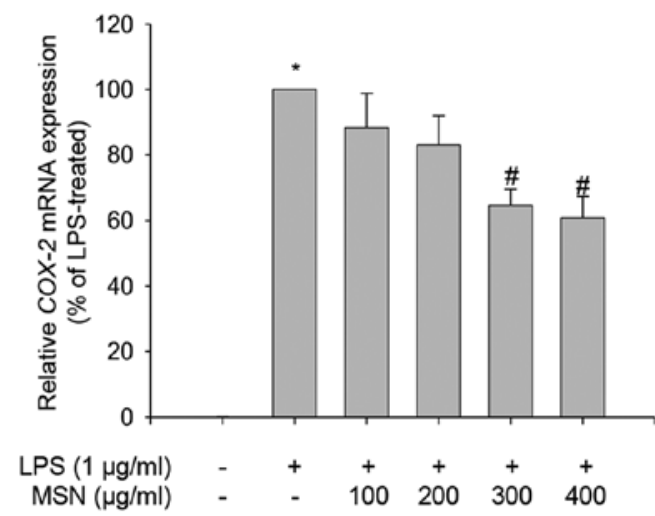

C

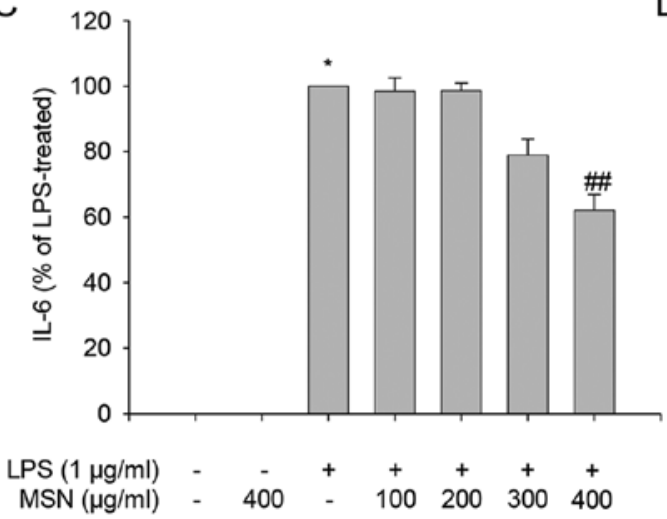

E

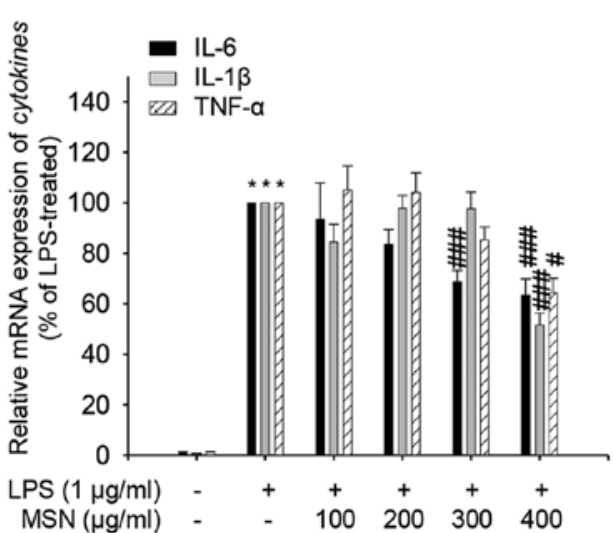

B
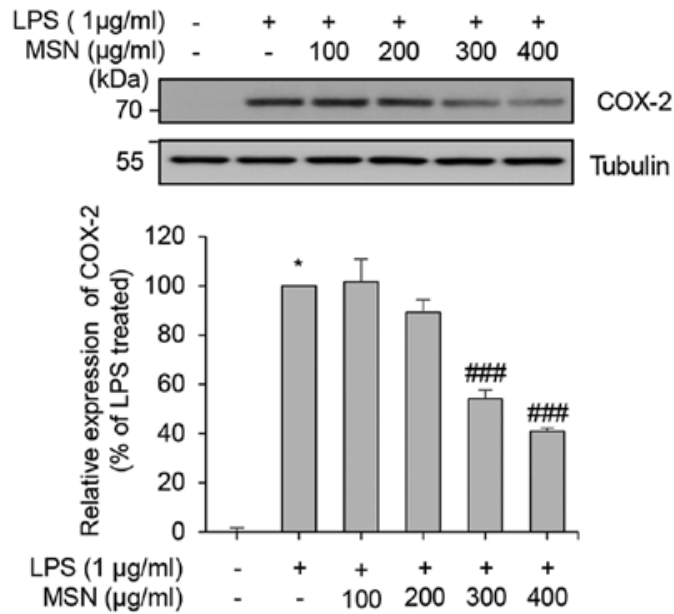

D

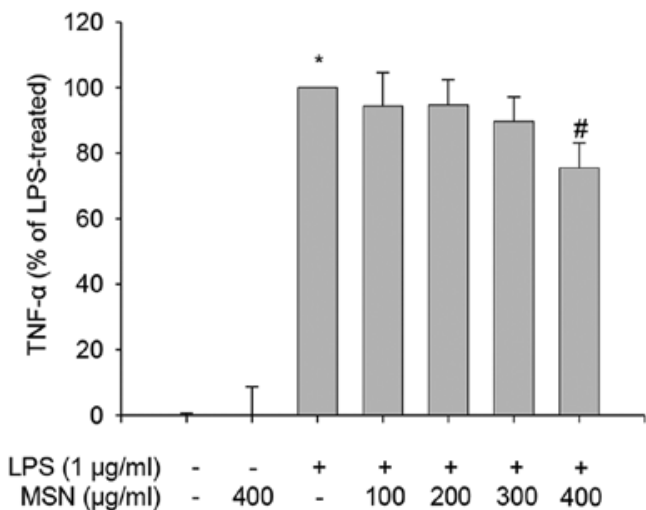

Figure 2. Inhibitory effects of MSN on pro-inflammatory mediators. RAW 264.7 macrophages were pre-treated with MSN (100, 200, 300, and 400 $\mu \mathrm{g} / \mathrm{ml})$ at $37^{\circ} \mathrm{C}$ for $2 \mathrm{~h}$ and then stimulated with LPS $(1 \mu \mathrm{g} / \mathrm{ml})$ for an indicated time. (A) After $3 \mathrm{~h}$ LPS stimulation, COX-2 was amplified by RT-qPCR, and the expression of each group was compared to that in the LPS-treated group. (B) Total cell lysates were collected after $24 \mathrm{~h}$ stimulation, and immunoblot analyses were performed. The protein expression levels of COX-2 were detected using ECL reagent and quantified by analysis with LabWorks software. All the protein levels were normalized to corresponding tubulin levels. Relative expression levels of COX-2 are represented as a bar graph. After stimulation for $24 \mathrm{~h}$, the levels of (C) IL-6 and (D) TNF- $\alpha$ in the cultured media were quantified using ELISA. The secretion of each cytokine was calculated using a standard curve. (E) After $24 \mathrm{~h}$ stimulation, IL-1 $\beta$, IL-6 and TNF- $\alpha$ were amplified by RT-qPCR, and the expression of each group was compared to that in the LPS-treated and MSN-untreated control group. Data are represented as the mean $\pm \mathrm{SEM}$. ${ }^{*} \mathrm{P}<0.01$ vs. LPS-untreated control group. ${ }^{\#} \mathrm{P}<0.05$, ${ }^{\# \#} \mathrm{P}<0.01$ and ${ }^{\# \# \#} \mathrm{P}<0.001$ vs. LPS-treated and MSN-untreated control group. MSN, methanol extract of Synedrella nodiflora (Linn.) Gaertn.; LPS, lipopolysaccharide; COX-2, cyclooxygenase-2; IL-6, interleukin-6; IL-1 $\beta$, interleukin-1 $\beta$; TNF- $\alpha$, tumor necrosis factor- $\alpha$.

phosphorylation and protein levels. As presented in Fig. 3A, LPS induced the phosphorylation and degradation of $\mathrm{I} x \mathrm{~B} \alpha$, while the phosphorylation of $\mathrm{I} \alpha \mathrm{B} \alpha$ decreased and $\mathrm{I} \alpha \mathrm{B} \alpha$ levels increased in the MSN-treated groups. These results suggest that MSN inhibits NF- $x \mathrm{~B}$ activation through the change in $\mathrm{I} x \mathrm{~B} \alpha$ phosphorylation.
Since MAPK signaling, another LPS-induced inflammatory signaling pathway, regulates the production of inflammatory cytokines and mediators (48), the regulation of MAPK signaling by MSN was investigated in the present study. Phosphorylation levels of p38, JNK, and ERK in their activation loop were increased in RAW 264.7 cells upon exposure to LPS (Fig. 3B). 
A
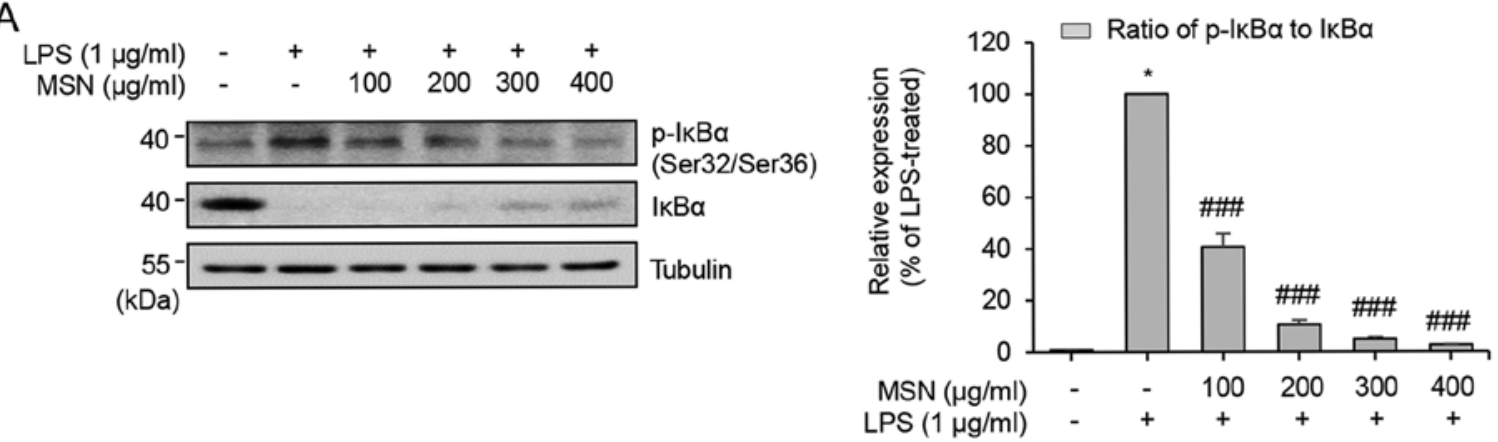

B
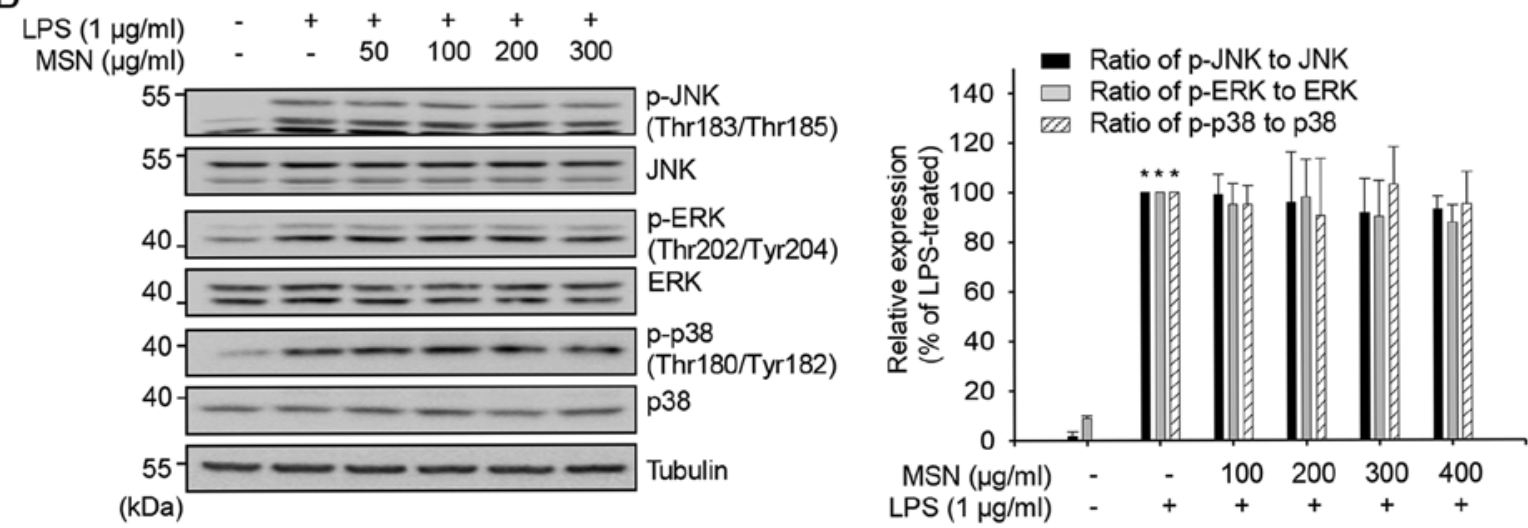

C
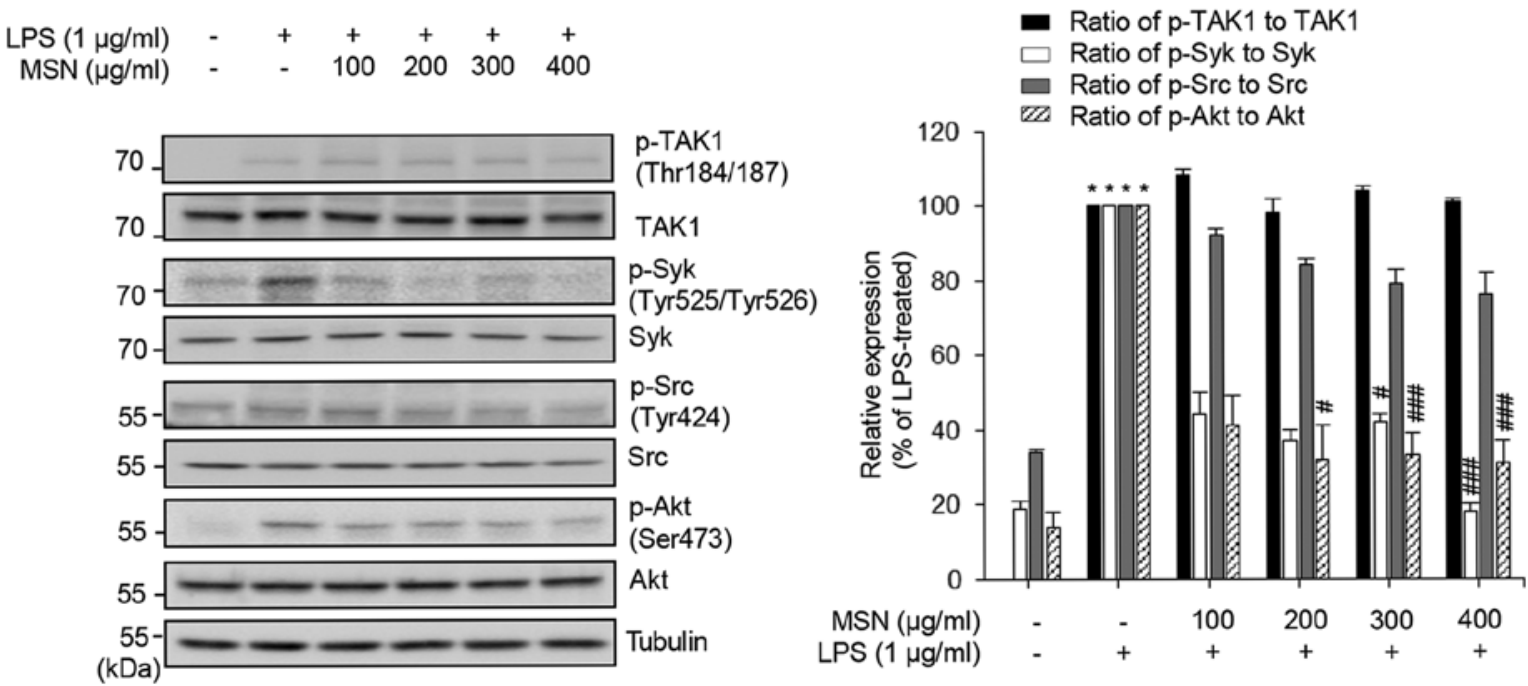

Figure 3. Inflammatory inhibition of MSN on MAPK phosphorylation and NF- $x \mathrm{~B}$ activation in RAW 264.7 macrophages. RAW 264.7 macrophages were pre-treated with MSN $(100,200,300$, and $400 \mu \mathrm{g} / \mathrm{ml})$ for $2 \mathrm{~h}$ and stimulated with LPS $(1 \mu \mathrm{g} / \mathrm{ml})$ at $37^{\circ} \mathrm{C}$ for indicated times. (A) After stimulation for $3 \mathrm{~min}$, total cell lysates were prepared and immunoblot analyses were performed. Tubulin was used as a loading control. Protein levels were quantified with LabWorks software. Relative expression levels of $\mathrm{I} \chi \mathrm{B} \alpha$ and $\mathrm{p}-\mathrm{I} \chi \mathrm{B} \alpha$ were normalized to tubulin levels and then the ratio of phosphorylated (p)-I $\mathrm{B} \alpha$ vs. total $\mathrm{I} \chi \mathrm{B} \alpha$ protein level is shown as a bar graph. (B) Total cell lysates were collected after 15 min of LPS treatment and subjected to immunoblot analysis using appropriate antibodies. Tubulin was used as a loading control. Protein levels were measured using LabWorks software. Levels of phosphorylated MAPKs were normalized to corresponding total MAPK levels. The ratio of phosphorylated vs. total protein level for each MAPK is shown as a bar graph after normalization. (C) Cells were lysed after 3 min stimulation. Samples were subjected to immunoblot analysis. p-TAK1, p-Syk, p-Src, p-Akt, TAK1, Syk, Src, and Akt protein expression levels were determined. The phosphorylation levels of TAK1, Syk, Src, and Akt were normalized to the corresponding total protein levels. The ratios of phosphorylated vs. total protein levels are shown as a bar graph. ${ }^{*} \mathrm{P}<0.01$ vs. LPS-untreated control group. ${ }^{\#} \mathrm{P}<0.05$ and ${ }^{\# \# \#} \mathrm{P}<0.001$ vs. LPS-treated and MSN-untreated control group. MSN, methanol extract of Synedrella nodiflora (Linn.) Gaertn.; LPS, lipopolysaccharide; I $\chi \mathrm{B} \alpha$, inhibitor of $\chi \mathrm{B} \alpha$; JNK, c-Jun N-terminal kinase; ERK, extracellular signal-regulated kinase; TAK1, transforming growth factor- $\beta$-activated kinase 1; Syk, spleen tyrosine kinase; Src, proto-oncogene tyrosine-protein kinase.

When the cells were treated with MSN prior to LPS stimulation, the levels of p-ERK, p-JNK, and p-p38 were not altered, suggesting that MSN has little effect on MAPK signaling.
TAK1 is an upstream signaling kinase of NF- $x \mathrm{~B}$ and MAPK signaling transduction (49). In addition, the TAK1-independent Syk/Src/Akt signaling pathway plays a vital role in NF- $x \mathrm{~B}$ 


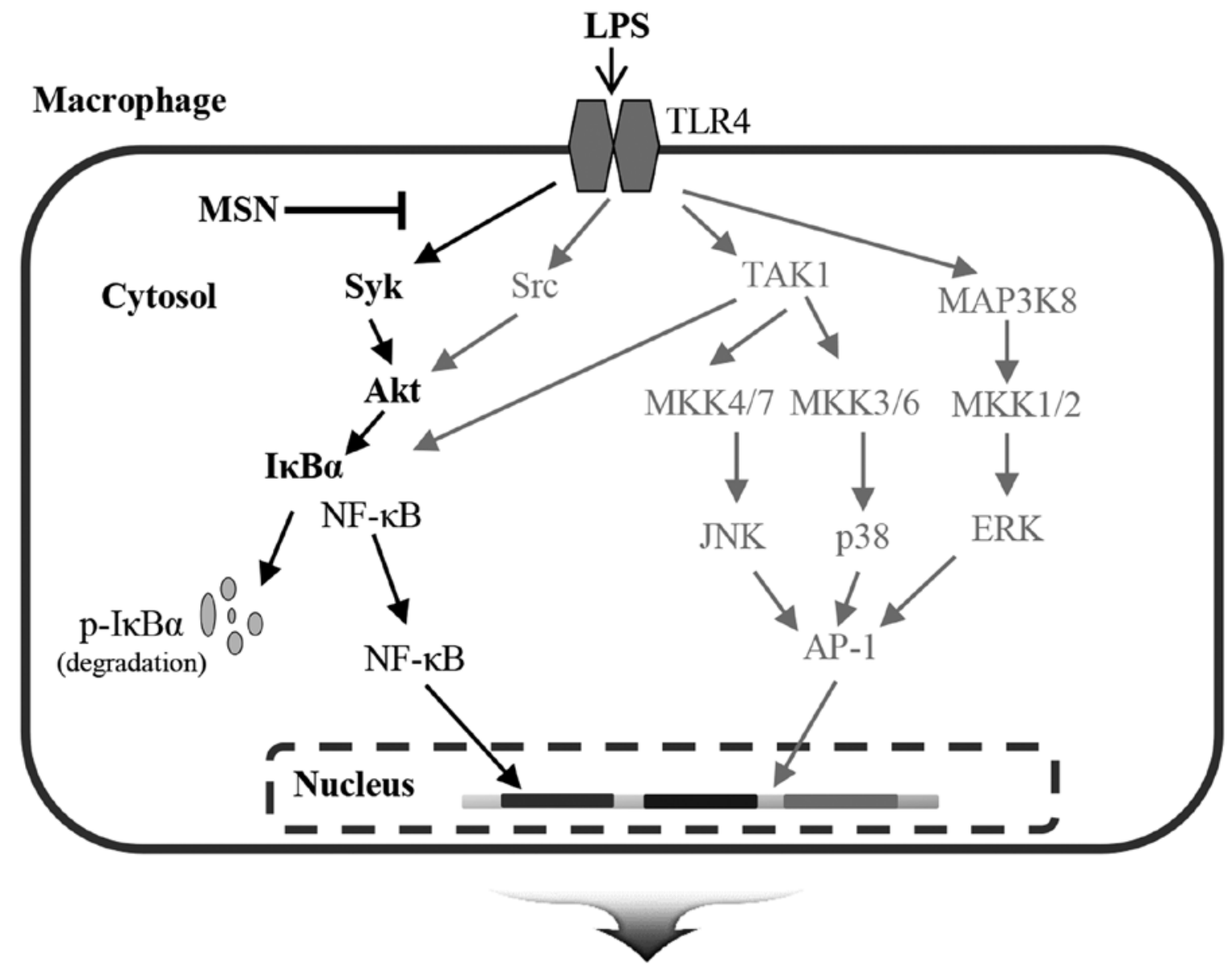

NO, PGE 2 , IL-6, IL-1ß, TNF- $\alpha$

Figure 4. The molecular pathway of the inflammatory effects of MSN in LPS-stimulated RAW 264.7 cells. MSN, methanol extract of Synedrella nodiflora (Linn.) Gaertn.; LPS, lipopolysaccharide; IL-6, interleukin-6; IL-1 $\beta$, interleukin-1 $\beta$; TNF- $\alpha$, tumor necrosis factor- $\alpha$; NO, nitric oxide; PGE ${ }_{2}$, prostaglandin $\mathrm{E}_{2}$; COX-2, cyclooxygenase-2; $\mathrm{I} \varkappa \mathrm{B} \alpha$, inhibitor of $\varkappa \mathrm{B} \alpha$; NF- $\chi \mathrm{B}$, nuclear factor $\varkappa \mathrm{B}$; Akt, protein kinase B; Src, proto-oncogene tyrosine-protein kinase; Syk, spleen tyrosine kinase; TLR4, toll-like receptor 4; TAK1, transforming growth factor- $\beta$-activated kinase 1 ; MAP3K8, mitogen-activated protein kinase kinase kinase 8; MKK, mitogen-activated protein kinase kinase; ERK, extracellular signal-regulated kinase; JNK, c-Jun N-terminal kinase; AP-1, activator protein 1.

activation (50). The effect of MSN on the phosphorylation of TAK1/Syk/Src/Akt at their activation sites was investigated by immunoblot analysis to identify the targets of MSN in the regulation of NF- $x \mathrm{~B}$ activation. The LPS-induced phosphorylation of Syk and Akt was reduced by MSN without changing the protein levels, whereas the phosphorylation of TAK 1 and Src was not affected by MSN (Fig. 3C). These results suggest that MSN suppresses the phosphorylation of Syk and its downstream factors of the NF- $x$ B pathway independently of TAK1 and Src.

\section{Discussion}

Despite the swift and proven efficacy of non-steroidal anti-inflammatory drugs, these drugs have the drawbacks of adverse side effects (51). Therefore, there have been efforts to develop anti-inflammatory drugs with fewer side effects and excellent healing effects (52). Among them, traditional and natural medicines have great benefits and potential $(53,54)$. Several traditional medicines such as Euphorbia cooperi and Thunbergia alata have been reported to exert anti-inflammatory effects in folk remedies $(24,29,55,56)$.
In the present study, a methanol extract of S.nodiflora (MSN) strongly suppressed the expression of inducible nitric oxide synthase (iNOS) in lipopolysaccharide (LPS)-stimulated RAW 264.7 cells in a dose-dependent manner. However, the $100 \mu \mathrm{g} / \mathrm{ml}$ MSN-treated group showed a prominent reduction on mRNA level compared that on protein level. This difference may be due to a variety of reasons, including transcriptional, post-transcriptional, translational and post-translational regulation, mRNA stability and protein stability (57-60). Moderate inhibitory activity on the production of tumor necrosis factor (TNF)- $\alpha$, interleukin (IL)-6, IL-1 $\beta$, and cyclooxygenase-2 (COX-2) was observed in the resent study. These results indicate that MSN may contain small amounts of anti-inflammatory components, inhibitors, or selective anti-inflammatory drugs. Analysis of the inflammation-regulated signaling pathways following treatment with MSN showed that only the NF- $x \mathrm{~B}$ pathway was affected by MSN. The MAPK signaling pathway, the other major signaling pathway regulating inflammation, was not inhibited by MSN. Since both the NF- $x$ B and MAPK pathways function in the regulation of inflammation $(46,48)$, these data indicate why MSN showed a mild effect on the expression of TNF- $\alpha$, IL-6, IL-1 $\beta$, and COX-2. Furthermore, analysis of 
spleen tyrosine kinase (Syk), proto-oncogene tyrosine-protein kinase (Src), and transforming growth factor- $\beta$-activated kinase 1 (TAK1), which are upstream regulators of the NF- $x \mathrm{~B}$ signaling pathway, showed that Syk was inhibited by MSN while Src and TAK1 were not regulated by MSN. The specific inhibition of Syk by MSN suggests that the anti-inflammatory role of MSN may be dependent on highly selective anti-inflammatory components constituting MSN, such as alkaloids, flavonoids, triterpenes, saponins, simple phenolics, glycosides, and polyose. Even though the constituents of MSN have been previously reported (29,30), High-performance liquid chromatography (HPLC) analysis of MSN is still needed for further study of MSN and its constituents together with the anti-inflammatory mechanisms, which is the limitation of the present study. In the present study, these anti-inflammatory components were interpreted as responsible for the selective inhibition of Syk, Akt, and NF- $\varkappa$ B pathways. Thus, further studies are needed to identify the specific functions of each anti-inflammatory component comprising MSN on selective inhibition.

One of the most prominent steps of inflammation is NO production by iNOS (61). Several studies have attempted to identify candidates for anti-inflammatory drugs and elucidate their mechanisms of action (62). In LPS-activated macrophages, induced NO serves as a pro-inflammatory mediator due to overproduction by iNOS. MSN inhibited the production of NO via decreased expression of both iNOS protein and mRNA in the present study. Furthermore, it is well known that the excessive production of prostaglandin $\mathrm{E}_{2}\left(\mathrm{PGE}_{2}\right)$ is related to inflammatory states (63), and COX-2 mediates the synthesis of $\mathrm{PGE}_{2}$ (64). MSN negatively regulated COX-2 expression at both the mRNA and protein levels in the LPS-stimulated RAW 264.7 macrophages. Several studies have attempted to confirm novel anti-inflammatory agents that inhibit iNOS and COX-2 expression and have demonstrated them as novel drugs for inflammatory treatment $(64,65)$. Therefore, data in the present study suggest that MSN may be used as a drug candidate to treat inflammatory disease.

In response to LPS stimulation, RAW 264.7 macrophages produce several cytokines, including IL-6, IL-1 $\beta$, and TNF- $\alpha$ (66). Previous studies have shown that $I L-1 \beta$ and $I L-6$ genes have both NF- $x \mathrm{~B}$ and STAT binding domain whereas the $T N F-\alpha$ promoter has NF- $\varkappa \mathrm{B}$ binding region but not STAT binding region $(67,68)$. In the present study, MSN inhibited LPS-induced IL- 6 and TNF- $\alpha$ production in macrophages. In addition, mRNA expression of $I L-6$, $I L-1 \beta$, and $T N F-\alpha$ was also reduced. This suggests that MSN is possibly involved in the regulation of the STAT3 signaling pathway and that both NF- $x \mathrm{~B}$ and STAT3 function in collaboration to regulate $I L-6$ and $I L-1 \beta$ genes, resulting in potent inhibition of these genes.

Binding of LPS to Toll-like receptors induces the activation of both MAPKs and NF- $x \mathrm{~B}$ (64). However, the activities of MAPKs and NF- $\varkappa \mathrm{B}$ are regulated by different upstream molecules, such as specific MAP3Ks and MAP2Ks for MAPKs and $\mathrm{I} x \mathrm{~B} \alpha$ kinases for NF- $x \mathrm{~B}$ (69). Following the LPS stimulation, $\mathrm{I} \chi \mathrm{B} \alpha$ is phosphorylated and degraded $(69,70)$. With the degradation of $\mathrm{I} x \mathrm{~B} \alpha, \mathrm{NF}-x \mathrm{~B}$ is unconstrained to enter the nucleus, where it chains to and triggers the transcription of target genes $(71,72)$. In the present study, MSN treatment suppressed $\mathrm{I} \varkappa \mathrm{B} \alpha$ phosphorylation dose-dependently, which in turn reduced $\mathrm{I} \chi \mathrm{B} \alpha$ degradation. When the degradation of $\mathrm{I} \varkappa \mathrm{B} \alpha$ is suppressed, NF- $\varkappa \mathrm{B}$ nuclear translocation is inhibited, which fails to transcribe its downstream target genes (72). Since the activity of NF- $x \mathrm{~B}$ is mostly regulated by $\mathrm{I} x \mathrm{~B} \alpha$ binding, NF- $x \mathrm{~B}$ target genes are potential targets of MSN treatment. In addition, upstream signaling of $\mathrm{I} \chi \mathrm{B} \alpha$ includes the TAK1/Syk/Src/Akt signaling pathway (73). MSN showed inhibitory effects by reducing the phosphorylation of Syk and Akt. Therefore, these findings support the hypothesis that MSN shows an anti-inflammatory effect by inhibiting NF- $x \mathrm{~B}$ activation.

Anti-oxidant, anti-bacterial, and even anti-psychotic effects as well as anti-inflammatory effects of MSN have been previously reported $(74,75)$. However, previous studies have focused on the chemical analysis of the constituents of MSN or the physiological effects of MSN in mouse models (76). In the present study, the anti-inflammatory effects and the underlying anti-inflammatory mechanisms of MSN were evaluated. The Syk/Akt/I $\chi \mathrm{B} \alpha$ pathway that is significantly suppressed by MSN provides insight for the further application of MSN in the development of anti-inflammatory agents. In addition, the mode of action needs to be investigated to reveal the target pathway of the extract or to avoid unexpected side effects.

In conclusion, the present study demonstrates that MSN exhibits anti-inflammatory properties via inhibition of the production of various inflammatory mediators such as NO, PGE $_{2}$, TNF- $\alpha$, IL- 6 , and IL-1 $\beta$. The inhibitory effects of MSN are dependent on the suppression of the Syk/Akt/I $\alpha \mathrm{B} \alpha$ signaling pathway and NF- $x \mathrm{~B}$ activation (Fig. 4). Therefore, these results support the traditional use of MSN in the treatment of several inflammation-associated diseases and suggest that the novelty of the present study lies in the revealed pathway. Thus, MSN is a candidate anti-inflammatory agent for the treatment of inflammation.

\section{Acknowledgements}

The authors would like to thank the KRIBB Initiative Program of the Republic of Korea for information on plant extract list and MSN.

\section{Funding}

The present study was financially supported by the Chung-Ang University Research Scholarship Grants in 2018 and by the National Research Foundation of Korea (NRF) grant funded by the Ministry of Science and ICT (grant no. NRF-2018R1A2B6005084).

\section{Availability of data and materials}

The datasets used and/or analyzed in the present study are available from the corresponding author on reasonable request.

\section{Authors' contributions}

HTTL and SC designed the study. HTTL and JP performed the data acquisition. JP performed the cell viability and immunoblot assays. HTTL, JP, JH, SK, JHP, and SC analyzed and 
interpreted the data. SK and JHP provided extraction methods and MSN. HTTL wrote the draft. JP, JH, SK, JHP, and SC revised the manuscript. All authors read and approved the manuscript and agree to be accountable for all aspects of the research in ensuring that the accuracy or integrity of any part of the work are appropriately investigated and resolved.

\section{Ethics approval and consent to participate}

Not applicable.

\section{Patient consent for publication}

Not applicable.

\section{Competing interests}

The authors declare that they have no competing interests.

\section{References}

1. Belkaid Y and Hand TW: Role of the microbiota in immunity and inflammation. Cell 157: 121-141, 2014.

2. Tamayo E, Fernández A, Almansa R, Carrasco E, Heredia M, Lajo C, Goncalves L, Gómez-Herreras JI, de Lejarazu RO and Bermejo-Martin JF: Pro- and anti-inflammatory responses are regulated simultaneously from the first moments of septic shock. Eur Cytokine Netw 22: 82-87, 2011.

3. Galkina E and Ley K: Immune and inflammatory mechanisms of atherosclerosis (*). Annu Rev Immunol 27: 165-197, 2009.

4. Mogensen TH: Pathogen recognition and inflammatory signaling in innate immune defenses. Clin Microbiol Rev 22: 240-273, 2009.

5. Balamayooran G, Batra S, Fessler MB, Happel KI and Jeyaseelan S: Mechanisms of neutrophil accumulation in the lungs against bacteria. Am J Respir Cell Mol Biol 43: 5-16, 2010

6. Thapa B and Lee K: Metabolic influence on macrophage polarization and pathogenesis. BMB Rep 52: 360-372, 2019.

7. Janssens $S$ and Beyaert R: Role of Toll-like receptors in pathogen recognition. Clin Microbiol Rev 16: 637-646, 2003.

8. Zhang JM and An J: Cytokines, inflammation, and pain. Int Anesthesiol Clin 45: 27-37, 2007.

9. Penna G, Mondaini N, Amuchastegui S, Degli Innocenti S, Carini M, Giubilei G, Fibbi B, Colli E, Maggi M and Adorini L: Seminal plasma cytokines and chemokines in prostate inflammation: Interleukin 8 as a predictive biomarker in chronic prostatitis/chronic pelvic pain syndrome and benign prostatic hyperplasia. Eur Urol 51: 524-533, discussion 533, 2007.

10. Arango Duque G and Descoteaux A: Macrophage cytokines: Involvement in immunity and infectious diseases. Front Immunol 5: 491, 2014.

11. Wu D, Liu J, Pang X, Wang S, Zhao J, Zhang X and Feng L: Palmitic acid exerts pro-inflammatory effects on vascular smooth muscle cells by inducing the expression of C-reactive protein inducible nitric oxide synthase and tumor necrosis factor- $\alpha$. Int J Mol Med 34: 1706-1712, 2014.

12. Forstermann U and Sessa WC: Nitric oxide synthases: regulation and function. Eur Heart J 33: 829-837, 837a-837d, 2012 https://doi.org/10.1093/eurheartj/ehr304..

13. Sun GY, Shelat PB, Jensen MB, He Y, Sun AY and Simonyi A Phospholipases A2 and inflammatory responses in the central nervous system. Neuromolecular Med 12: 133-148, 2010.

14. Yang $\mathrm{H}$ and Chen $\mathrm{C}$ : Cyclooxygenase-2 in synaptic signaling. Curr Pharm Des 14: 1443-1451, 2008.

15. Mbonye UR and Song I: Posttranscriptional and posttranslational determinants of cyclooxygenase expression. BMB Rep 42: 552-560, 2009.

16. Ricciotti E and FitzGerald GA: Prostaglandins and inflammation. Arterioscler Thromb Vasc Biol 31: 986-1000, 2011.

17. Cekici A, Kantarci A, Hasturk H and Van Dyke TE: Inflammatory and immune pathways in the pathogenesis of periodontal disease. Periodontol 2000 64: 57-80, 2014.
18. Lucas SM, Rothwell NJ and Gibson RM: The role of inflammation in CNS injury and disease. Br J Pharmacol 147 (Suppl 1): S232-S240, 2006.

19. Fuentes AL, Millis L, Vapenik J and Sigola L: Lipopolysaccharide-mediated enhancement of zymosan phagocytosis by RAW 264.7 macrophages is independent of opsonins, laminarin, mannan, and complement receptor 3. J Surg Res 189: 304-312, 2014

20. Taciak B, Białasek M, Braniewska A, Sas Z, Sawicka P, Kiraga $€$, Rygiel T and Król M: Evaluation of phenotypic and functional stability of RAW 264.7 cell line through serial passages. PLoS One 13: e0198943, 2018.

21. Amoateng P, Adjei S, Osei-Safo D, Kukuia KKE, Bekoe EO, Karikari TK and Kombian SB: Extract of Synedrella nodiflora (L) Gaertn exhibits antipsychotic properties in murine models of psychosis. BMC Complement Altern Med 17: 389, 2017.

22. Gruca M, van Andel TR and Balslev H: Ritual uses of palms in traditional medicine in sub-Saharan Africa: A review. J Ethnobiol Ethnomed 10: 60, 2014.

23. Amoateng P, Woode E and Kombian SB: Anticonvulsant and related neuropharmacological effects of the whole plant extract of Synedrella nodiflora (L.) Gaertn (Asteraceae). J Pharm Bioallied Sci 4: 140-148, 2012

24. Amoateng P, Adjei S, Osei-Safo D, Ahedor B, Mahmood SA, N'guessan BB, Asiedu-Gyekye IJ and Nyarko AK: Long-term continuous administration of a hydro-ethanolic extract of Synedrella nodiflora (L) Gaertn in male Sprague-Dawley rats: Biochemical, haematological and histopathological changes. Ghana Med J 50: 163-171, 2016.

25. Mulla W, Kuchekar S, Thorat V, Chopade A and Kuchekar B: Antioxidant, antinociceptive and anti-inflammatory activities of ethanolic extract of leaves of Alocasia indica (Schott.). J Young Pharm 2: 137-143, 2010.

26. Ghaisas MM, Dandawate PR, Zawar SA, Ahire YS and Gandhi SP: Antioxidant, antinociceptive and anti-inflammatory activities of atorvastatin and rosuvastatin in various experimental models. Inflammopharmacology 18: 169-177, 2010.

27. Ghayal N, Dhumal K, Deshpande N, Ruikar A and Phalgune U: Phytotoxic effects of leaf leachates of an invasive weed Synedrella nodiflora and characterization of its allelochemical. Int J Pharm Sci Rev Res 19: 79-86, 2013.

28. Aalbersberg WG and Singh Y: Essential oils from two medicinal plants of Fiji: Dysoxylum richii (A. Gray) CDC fruit and Synedrella nodiflora (L.) Gaertn. leaves. Flavour Fragrance J 6: 125-128, 1991.

29. Amoateng P, Adjei S, Osei-Safo D, Ameyaw EO, Ahedor B, N'guessan BB and Nyarko AK: A hydro-ethanolic extract of Synedrella nodiflora (L.) Gaertn ameliorates hyperalgesia and allodynia in vincristine-induced neuropathic pain in rats. J Basic Clin Physiol Pharmacol 26: 383-394, 2015.

30. Adjibode A, Tougan U, Youssao A, Mensah G, Hanzen C and Koutinhouin G: Synedrella nodiflora (L.) Gaertn: A review on its phytochemical screening and uses in animal husbandry and medicine. Int J Adv Sci Tech Res 3: 436-443, 2015.

31. Cho JY, Yoo ES, Cha BC, Park H-J, Rhee MH and Han YN: The inhibitory effect of triterpenoid glycosides originating from Sanguisorba officinalis on tissue factor activity and the production of TNF- $\alpha$. Planta Med 72: 1279-1284, 2006.

32. Sethi G, Ahn KS, Pandey MK and Aggarwal BB: Celastrol, a novel triterpene, potentiates TNF-induced apoptosis and suppresses invasion of tumor cells by inhibiting NF-kappaB-regulated gene products and TAK1-mediated NF-kappaB activation. Blood 109: 2727-2735, 2007.

33. Serafini M, Peluso I and Raguzzini A: Flavonoids as anti-inflammatory agents. Proc Nutr Soc 69: 273-278, 2010.

34. Lee S, Kim YJ, Kwon S, Lee Y, Choi SY, Park J and Kwon HJ: Inhibitory effects of flavonoids on TNF-alpha-induced IL-8 gene expression in HEK 293 cells. BMB Rep 42: 265-270, 2009.

35. Wen H, Jiang L, Zhang D, Yuan X, Dang J, Mei L, Shao Y and Tao Y: Anti-inflammatory activity of total alkaloids from Hypecoum leptocarpumhook. f. et Thoms. Pharmacogn Mag 14: 397-403, 2018.

36. Obasi TC, Braicu C, Iacob BC, Bodoki E, Jurj A, Raduly L, Oniga I, Berindan-Neagoe I and Oprean R: Securidaca-saponins are natural inhibitors of AKT, MCL-1, and BCL2L1 in cervical cancer cells. Cancer Manag Res 10: 5709-5724, 2018.

37. Glenn CR: Earth's Endangered Creatures, 2006. http://earthsendangered.com. Accession date: January 31, 2020.

38. International Union for Conservation of Nature and Natural Resources (IUCN): The IUCN Red List of Threatened Species. 2019. https://www.iucn.org. Accession date: January 31, 2020. 
39. Le HTT, Cho YC and Cho S: Methanol extract of Guettarda speciosa Linn. inhibits the production of inflammatory mediators through the inactivation of Syk and JNK in macrophages. Int J Mol Med 41: 1783-1791, 2018.

40. Livak KJ and Schmittgen TD: Analysis of relative gene expression data using real-time quantitative PCR and the 2(- $\Delta \Delta \mathrm{C}(\mathrm{T}))$ Method. Methods 25: 402-408, 2001.

41. Kim BR, Cho YC, Le HTT, Vuong HL, Lee S and Cho S: Suppression of inflammation by the rhizome of Anemarrhena asphodeloides via regulation of nuclear factor- $x \mathrm{~B}$ and $\mathrm{p} 38$ signal transduction pathways in macrophages. Biomed Rep 6: 691-697, 2017.

42. Haque A, Zahan R, Nahar L, Mosaddik A and Haque E: Anti-inflammatory and insecticidal activities of Synedrella nodiflora. Mol Clin Pharmacol 2012: 60-67, 2012.

43. Pacher P, Beckman JS and Liaudet L: Nitric oxide and peroxynitrite in health and disease. Physiol Rev 87: 315-424, 2007.

44. Di Meo S, Reed TT, Venditti P and Victor VM: Role of ROS and RNS sources in physiological and pathological conditions. Oxid Med Cell Longev 2016: 1245049, 2016.

45. Giuliano F and Warner TD: Origins of prostaglandin E2: Involvements of cyclooxygenase (COX)- 1 and COX-2 in human and rat systems. J Pharmacol Exp Ther 303: 1001-1006, 2002.

46. Choi YH, Kim GY and Lee HH: Anti-inflammatory effects of cordycepin in lipopolysaccharide-stimulated RAW 264.7 macrophages through Toll-like receptor 4-mediated suppression of mitogen-activated protein kinases and NF- $x \mathrm{~B}$ signaling pathways. Drug Des Devel Ther 8: 1941-1953, 2014.

47. Majumdar S and Aggarwal BB: Methotrexate suppresses NF-kappaB activation through inhibition of IkappaBalpha phosphorylation and degradation. J Immunol 167: 2911-2920, 2001.

48. Newton K and Dixit VM: Signaling in innate immunity and inflammation. Cold Spring Harb Perspect Biol 4: 4, 2012.

49. Chen F, Demers LM and Shi X: Upstream signal transduction of NF-kappaB activation. Curr Drug Targets Inflamm Allergy 1: 137-149, 2002

50. Lin YC, Huang DY, Chu CL, Lin YL and Lin WW: The tyrosine kinase Syk differentially regulates Toll-like receptor signaling downstream of the adaptor molecules TRAF6 and TRAF3. Sci Signal 6: ra71, 2013

51. Ong CK, Lirk P, Tan CH and Seymour RA: An evidence-based update on nonsteroidal anti-inflammatory drugs. Clin Med Res 5: 19-34, 2007.

52. Weaver CS and Terrell KM: Evidence-based emergency medicine. Update: Do ophthalmic nonsteroidal anti-inflammatory drugs reduce the pain associated with simple corneal abrasion without delaying healing? Ann Emerg Med 41: 134-140, 2003.

53. Luesch $\mathrm{H}$ and Abreu P: A natural products approach to drug discovery: Probing modes of action of antitumor agents by genome-scale cDNA library screening. Methods Mol Biol 572: 261-277, 2009.

54. Prisinzano TE: Natural products as tools for neuroscience: Discovery and development of novel agents to treat drug abuse. J Nat Prod 72: 581-587, 2009.

55. Cho YC, Lee IS, Seo H, Ju A, Youn D, Kim Y, Choun J and Cho S: Methanol extracts of Euphorbia cooperi inhibit the production of inflammatory mediators by inhibiting the activation of c-Jun $\mathrm{N}$-terminal kinase and p38 in murine macrophages. Mol Med Rep 10: 2663-2668, 2014

56. Cho YC, Kim YR, Kim BR, Bach TT and Cho S: Thunbergia alata inhibits inflammatory responses through the inactivation of ERK and STAT3 in macrophages. Int J Mol Med 38: 1596-1604, 2016.

57. de Sousa Abreu R, Penalva LO, Marcotte EM and Vogel C. Global signatures of protein and mRNA expression levels. Mol Biosyst 5: 1512-1526, 2009

58. Vogel C and Marcotte EM: Insights into the regulation of protein abundance from proteomic and transcriptomic analyses. Nat Rev Genet 13: 227-232, 2012.
59. Maier T, Güell M and Serrano L: Correlation of mRNA and protein in complex biological samples. FEBS Lett 583: 3966-3973, 2009.

60. Fekete T, Rásó E, Pete I, Tegze B, Liko I, Munkácsy G, Sipos N, Rigó J Jr and Györffy B: Meta-analysis of gene expression profiles associated with histological classification and survival in 829 ovarian cancer samples. Int J Cancer 131: 95-105, 2012.

61. Wojdasiewicz P, Poniatowski LA and Szukiewicz D: The role of inflammatory and anti-inflammatory cytokines in the pathogenesis of osteoarthritis. Mediators Inflamm 2014: 561459, 2014

62. Gilroy DW: New insights into the anti-inflammatory actions of aspirin-induction of nitric oxide through the generation of epi-lipoxins. Mem Inst Oswaldo Cruz 100 (Suppl 1): 49-54, 2005.

63. Dinarello CA: Anti-inflammatory agents: Present and future. Cell 140: 935-950, 2010.

64. Aggarwal BB, Prasad S, Reuter S, Kannappan R, Yadev VR, Park B, Kim JH, Gupta SC, Phromnoi K, Sundaram C, et al: Identification of novel anti-inflammatory agents from Ayurvedic medicine for prevention of chronic diseases: 'reverse pharmacology' and 'bedside to bench' approach. Curr Drug Targets 12: 1595-1653, 2011

65. Pan MH, Chiou YS, Tsai ML and Ho CT: Anti-inflammatory activity of traditional Chinese medicinal herbs. J Tradit Complement Med 1: 8-24, 2011.

66. Türe-Özdemir F, Tulunay A, Elbasi MO, Tatli I, Maurer AM, Mumcu G, Direskeneli $H$ and Eksioglu-Demiralp E: Pro-inflammatory cytokine and caspase-1 responses to pattern recognition receptor activation of neutrophils and dendritic cells in Behcet's disease. Rheumatology (Oxford) 52: 800-805, 2013.

67. Hubackova S, Krejcikova K, Bartek J and Hodny Z: Interleukin 6 signaling regulates promyelocytic leukemia protein gene expression in human normal and cancer cells. J Biol Chem 287: 26702-26714, 2012.

68. Friedrichsen S, Harper CV, Semprini S, Wilding $M$, Adamson AD, Spiller DG, Nelson G, Mullins JJ, White MR and Davis JR: Tumor necrosis factor-alpha activates the human prolactin gene promoter via nuclear factor-kappaB signaling. Endocrinology 147: 773-781, 2006.

69. Torres J, Enríquez-de-Salamanca A, Fernández I, Rodríguez-Ares MT,Quadrado MJ,Murta J,Benítez del CastilloJM, Stern ME and Calonge M: Activation of MAPK signaling pathway and NF-kappaB activation in pterygium and ipsilateral pterygium-free conjunctival specimens. Invest Ophthalmol Vis Sci 52: 5842-5852, 2011.

70. Bendoraite A,KnoufEC,Garg KS,ParkinRK,KrohEM,O'BriantKC, Ventura AP, Godwin AK, Karlan BY, Drescher CW, et al: Regulation of miR-200 family microRNAs and ZEB transcription factors in ovarian cancer: Evidence supporting a mesothelial-to-epithelial transition. Gynecol Oncol 116: 117-125, 2010.

71. Limb JK, Yoon S, Lee KE, Kim BH, Lee S, Bae YS, Jhon GJ and Kim J: Regulation of megakaryocytic differentiation of K562 cells by FosB, a member of the Fos family of AP-1 transcription factors. Cell Mol Life Sci 66: 1962-1973, 2009.

72. Oeckinghaus A and Ghosh S: The NF-kappaB family of transcription factors and its regulation. Cold Spring Harb Perspect Biol 1: a000034, 2009

73. Lowell CA: Src-family and Syk kinases in activating and inhibitory pathways in innate immune cells: Signaling cross talk. Cold Spring Harb Perspect Biol 3: 3, 2011.

74. Nahar L, Zahan R, Morshed MTI, Haque A, Alam Z and Mosaddik A: Antioxidant, analgesic and CNS depressant effects of Synedrella nodiflora. Pharmacogn J 4: 29-36, 2012.

75. Wijaya S, Nee TK, Jin KT, Hon LK, San LH and Wiart C: Antibacterial and antioxidant activities of Synedrella nodiflora (L.) Gaertn. (Asteraceae). J Complement Integr Med 8: 8, 2011.

76. Gnanaraj C, Shah MD, Haque AT, Makki JS and Iqbal M: Hepatoprotective and immunosuppressive effect of Synedrella nodiflora L. on carbon tetrachloride (CCl4)-intoxicated rats. J Environ Pathol Toxicol Oncol 35: 29-42, 2016. 